\title{
Review
}

\section{Possible effects of (trans)gene flow from crops on the genetic diversity from landraces and wild relatives}

\author{
Paul GEPTS ${ }^{1, *}$ and Roberto PAPA $^{2}$ \\ ${ }^{1}$ Department of Agronomy and Range Science, University of California, 1 Shields Avenue, Davis, CA 95616-8515, USA \\ 2 Dipartimento di Biotecnologie Agrarie ed Ambientali, Università Politecnia delle Marche, Via Brecce Bianche, 60131 Ancona, Italy
}

\begin{abstract}
Gene flow is a potential concern associated with the use of transgenic crops because it could affect genetic diversity of related landraces and wild relatives. This concern has taken on added importance with the looming introduction of transgenic crops in centers of crop domestication (Mexico, China) and those producing pharmaceutical compounds. For gene flow to take place among cultivars and their wild relatives, several steps have to be fulfilled, including the presence of cultivars or wild relatives within pollen or seed dispersal range, the ability to produce viable and fertile hybrids, at least partial overlap in flowering time, actual gene flow by pollen or seed, and the establishment of crop genes in the domesticated or wild recipient populations. In contrast with domestication genes, which often make crops less adapted to natural ecosystems, transgenes frequently represent gains of function, which might release wild relatives from constraints that limit their fitness. In most sexually reproducing organisms, the chromosomal region affected by selection of a single gene amounts to a small percentage of the total genome size. Because of gene flow, the level of genetic diversity present in the domesticated gene pool becomes a crucial factor affecting the genetic diversity of the wild gene pool. For some crops, such as cotton and maize, the introduction of transgenic technologies has led to a consolidation of the seed industry and a reduction in the diversity of the elite crop gene pool. Thus, diversity in improved varieties grown by farmers needs to be monitored. Several areas deserve further study, such as the actual magnitude of gene flow and its determinants in different agroecosystems, the long-term effects of gene flow on genetic diversity both across gene pools and within genomes, the expression of transgenes in new genetic backgrounds, and the effects of socio-economic factors on genetic diversity.
\end{abstract}

Keywords: genetic diversity / gene flow / selection / domestication / wild progenitor / seed industry / transgene

\section{INTRODUCTION}

Gene flow leading to the escape of transgenes is often cited as a potential concern associated with the introduction of transgenic cultivars (Goodman and Newell, 1985; Ellstrand, 2001; Snow, 2002). Consequences and concerns of gene flow mainly include the potential change (increase) in fitness of wild relatives and the concomitant risk of increased weediness, the loss of herbicide resistance as a tool to protect the crop from closely related weeds, and the effects on the genetic identity and diversity of sexually compatible relatives. The latter concern has taken on added urgency with the presence of transgenic maize in Mexico, its center of origin and diversity (Quist and Chapela, 2001; 2002), and the possible commercial release of rice and soybean in China (Huang et al., 2002), which is the center of domestication of these two crops (Gepts, 2001). Centers of origin and diversity often contain crop landraces with a wide array of phenotypic diversity, as well as wild progenitors and related wild species. This genetic diversity is the capital for current and future improvement of crop plants. Numerous

\footnotetext{
* Corresponding author:

Tel.: +1-530-752-7743; fax: +1-530-752-4361; e-mail: plgepts@ucdavis.edu
} 
factors impinge on the continued survival of this genetic diversity, including biological and anthropic factors. In this review, we discuss some issues related to one of these factors influencing genetic diversity, namely gene flow.

Biodiversity refers to the amazing array of organisms present on earth. The Convention on Biological Diversity in its Article 2 defines biological diversity as "the variability of living organisms of all types, including, among others, terrestrial ecosystems, marine and other aquatic ecosystems, and the ecological complexes to which they belong; this also includes diversity within species, between species and ecosystems" (Convention on Biological Diversity, 1992). Increasingly, biodiversity also includes human cultural diversity, including languages, religions, ideologies, artistic heritages, domesticated plants and animals, etc. (Albagli, 2002; Brush, 1995). From the standpoint of crop gene flow, it is mainly the diversity within species as well as that between the crop and closely related species that is relevant for this discussion.

It is beyond the scope of this review to examine the importance of biodiversity in general. The reader is referred to other sources for an in-depth discussion on the importance of biodiversity, its role in ecosystem function, and its conservation (Convention on Biological Diversity, 1992; Heywood et al., 1995; Loreau et al., 2002; Wood and Lenné, 1999).

\section{CROP GENETIC DIVERSITY AND ITS CHARACTERIZATION}

The importance of the genetic diversity of crops can be examined from two different perspectives. From one perspective, genetic diversity may be a necessary condition to achieve high productivity and yield stability. From the other perspective, genetic diversity is the raw material used by plant breeders over the long term to develop improved plant varieties. In agroecosystems, diversity - in a simplified version compared to natural ecosystems - also leads to higher total yields. This is illustrated by the many types of multiple cropping and agroforestry systems in use in the world, mainly in developing countries in subsistence-agriculture settings (Beets, 1982; Francis, 1986). In these systems, careful choice of the genotypes of the individual crops and the actual planting arrangements (e.g., density, planting time) can lead to a cropping system where the total biomass produced is larger than the sum of the biomasses of the individual components grown in monoculture. Plant breeders have selected genotypes specifically for high productivity under these multiple cropping conditions (Francis, 1985). Recently, Zhu et al. (2000) showed that a simple mixture of rice varieties (Oryza sativa $\mathrm{L}$.) was effective in limiting the infection of rice blast (Magnaporthe grisea (Hebert) Barr.) compared to a rice monoculture in China, thus preventing the need of a fungicide treatment. However, the results are mixed, as illustrated by those of Schultheis et al. (1997) in cucumber (Cucumis sativus L.) showing that only a very specific pair of cultivars yielded more than either of the components individually. In developing countries, nevertheless, farmers may grow mixtures of plant varieties (e.g., Martin and Adams, 1987a; 1987b) not only to maximize yield, but also to satisfy different needs, such as different types of culinary preparations or other uses, and to minimize risk.

The second perspective on genetic diversity deals with the utilitarian aspect of genetic resources in breeding. Until the advent of plant transformation technologies, access to genetic diversity in breeding programs was limited by sexual incompatibility. Plant breeders recognized three major gene pools based on the degree of sexual compatibility (Fig. 1; Gepts, 2000; Harlan and de Wet, 1971). Crosses within the primary gene pool, which includes the crop and its wild progenitor, do not encounter any reproductive isolation, in contrast to crosses between the primary gene pool, on one hand, and the secondary and tertiary gene pools, on the other. Plant breeders have traditionally emphasized closely related, well-adapted domesticated materials within the primary gene pool as sources of genetic diversity (e.g., Kelly et al., 1998). More recently, however, plant transformation and genomics have led to a fourth gene pool. Transgenesis allows us to bypass sexual incompatibility barriers altogether and introduce new genes into existing cultivars. It should be emphasized here that the major function of transgenic technologies is not the creation of new cultivars but the generation of new gene combinations that can be used in breeding programs (Gepts, 2002). Comparative genomics provides the means to identify sequences in a crop of agronomic interest based on homology of DNA sequences, transcription patterns, etc., with similar data in model systems such as Arabidopsis (Arabidopsis thaliana (L.) Heynh.) and rice (Gepts, 2000).

Over the last few decades, awareness of the rich diversity of exotic or wild germplasm has increased. This has lead to a more intensive use of this germplasm in breeding (Frey, 1975; Rick, 1982; Stalker, 1980). The use of molecular markers has facilitated the identification of genes of agronomic interest in wild germplasm through 


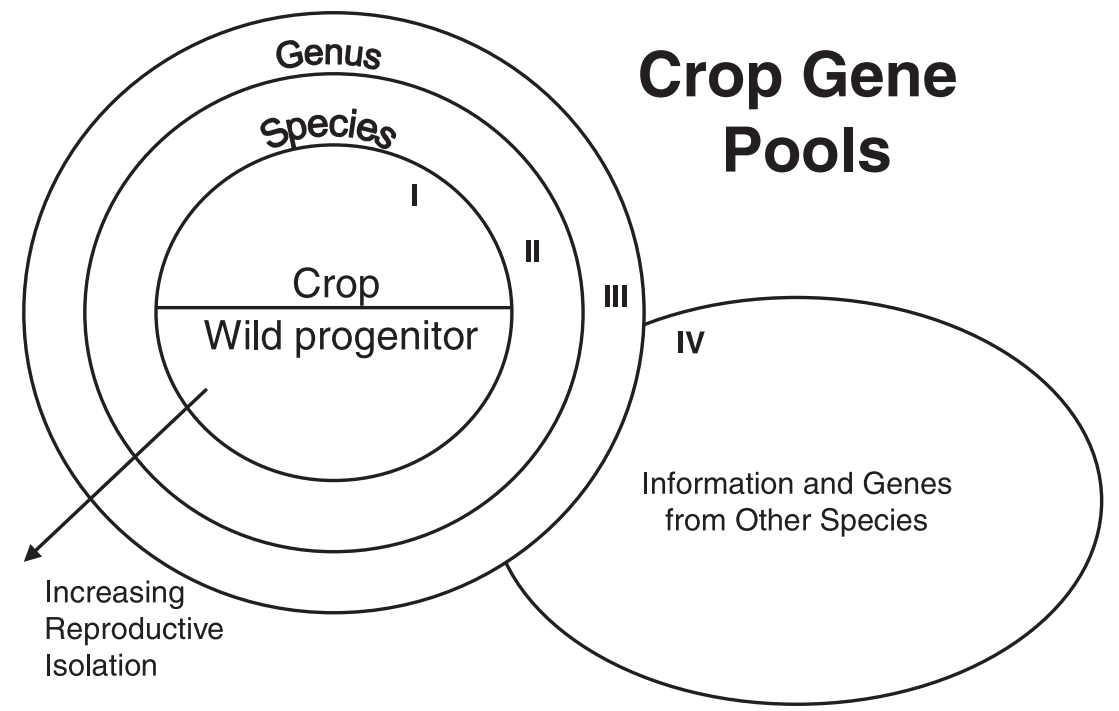

Figure 1. Crop gene pools as sources of genetic diversity for breeding purposes (from Gepts, 2000). Information from other genes refers to comparative genomic information on gene order and DNA sequence of homologous genes. the dissection of quantitative traits using linkage-mapbased approaches (Tanksley and McCouch, 1997). The same technology helps transfer these genes into superior varieties and accelerates the whole breeding process. Thus, genetic diversity of crop relatives is an increasingly accessible resource that needs to be protected for current and future use. A necessary condition for any genetic diversity study is the availability of adequate plant material. Large germplasm collections exist internationally. However, these can only provide the materials for certain types of experiments or hypotheses, such as germplasmwide analyses of diversity. For other experiments, such as comparisons of genetic diversity in relation to specific spatial distribution patterns, special surveys and collections have to be conducted.

Characterization of genetic diversity of organisms can be achieved with phenotypic traits and molecular markers, which may not always be correlated (Reed and Frankham, 2001). Phenotypic traits have the advantage that they may be directly related to the fitness of the populations and usefulness for plant breeding. A thorough evaluation of these traits, however, requires multi-location, multi-year trials to account for environmental effects and genotype $\times$ environment interactions. There currently exists a wide range of molecular markers that can be used to characterize genetic diversity, each with its own set of advantages and disadvantages. Many of these classes of markers, such as RAPDs and AFLPs, require little prior genetic knowledge of the species of interest. Microsatellite markers are very attractive for gene flow studies given the high level of polymorphism and their co-dominance
(Rafalski and Tingey, 1993). It is becoming increasingly easy to develop these types of markers genomic libraries developed specifically for this purpose (Zane et al., 2002). Furthermore, genomics efforts in major crops - such as expressed sequence tag (EST) development also provide microsatellites (e.g., Marek et al., 2001) and candidate genes for specific phenotypic traits (e.g., maize, Zea mays L.: Wang et al., 1999; 2001; common bean, Phaseolus vulgaris L.: Geffroy et al., 1999; 2000). Assessing diversity with actual genes responsible for evolutionarily important traits affecting fitness, such as reproduction, growth habit, resistance to diseases, and tolerance to abiotic stresses, may assist in improving the correlation between molecular and phenotypic analyses of genetic diversity.

Joint analyses of molecular and phenotypic diversity, as well as attempts at predicting the breeding value for different phenotypic traits depending on the molecular marker diversity or genotype of the parents, generally show a poor correlation between the two types of data (Reed and Frankham, 2001; McKay and Latta, 2002). This situation can be attributed to a variety of reasons, principally the lack of tight linkage between molecular markers (mainly neutral) and genes coding for phenotypic traits that may be subjected to selection. Other possible reasons include the lack of correspondence in gene action between phenotypic traits (additive, dominance, or epistatic actions) and molecular markers (indirect measure of additive gene action), differences in heritability (low to high for phenotypic traits $v s$. high for molecular markers), mutation rate and mutational input (high for polygenic phenotypic traits vs. low for molecular 
markers). Various authors have therefore proposed to assess, and select for, genetic diversity by analyzing genes directly involved in the traits of interest. Such studies include those of Delaney and Bliss (1991a; 1991b) on selection for seed protein, of van Tienderen et al. (2002) on "ecologically important" traits such as disease resistance, stress tolerance, growth rate, morphology and lifehistory traits, and Whitt et al. (2002) for genes coding enzymes of the starch metabolism pathway.

\section{THE EFFECT ON GENETIC DIVERSITY OF GENE FLOW AMONG DOMESTICATED GENOTYPES AND BETWEEN DOMESTICATED GENOTYPES AND THEIR WILD RELATIVES}

As shown in Figure 1, crops generally belong to the same biological species as their wild progenitor (gene pool I). Thus, they can cross easily with these progenitors. Moreover, their progenies are viable and fertile. A survey of the 13 most important crops on a worldwide basis showed 12 of these crops hybridized with their wild progenitors (Ellstrand et al., 1999; Hancock et al., 1996). The phenomenon is therefore widespread and has likely existed since the origins of agriculture some 10000 years ago. Moreover, progenies of domesticated $\times$ wild crosses are often viable and fertile and can even show hybrid vigor (Hauser et al., 1998a; 1998b; Koenig and Gepts, 1989; Singh et al., 1995; Snow et al., 1998). Identification of hybrids is based on morphological markers but increasingly also on molecular markers, which provide a much larger number of markers (Linder et al., 1998; Singh et al., 1991). The development of "pharming" crops, transformed with genes coding for pharmaceuticals (Schünmann et al., 2002; Stoger et al., 2000), has raised concerns over the escape by gene flow of those genes into other varieties of the crop. This is of special concern as the crop used in pharming are often food crops such as maize. Although this issue is not directly related to genetic diversity per se, it does arise from gene flow.

From the perspective of this discussion, gene flow from transgenic cultivars to landraces in centers of domestication is of particular importance. Recent articles by Quist and Chapela $(2001 ; 2002)$ raise this important issue for maize in Mexico. They reported two controversial findings. First, they identified transgenic sequences in landraces of the state of Oaxaca, Mexico. These sequences were homologous to the $35 \mathrm{~S}$ promoter of Cauliflower Mosaic Virus, which is often used in transgene constructs because it provides high levels of constitutive gene expression throughout the plant.
Second, they suggested that presumed rearrangements of transgene sequences at the insertion site in the maize genome or translocations of transgene sequences from the insertion site to other sites of the maize genome had taken place. The first finding is now generally accepted as being in the realm of possibilities given the importations of maize from the USA into Mexico and the sale of such maize for human consumption in official Mexican government stores (see next to last section of this review). Confirmatory evidence for the second finding is lacking so far. Given the importance of the topic, further research is needed to document the extent of the introgression phenomenon, the possibility of transgene rearrangement and instability, and any effect positive or negative - of transgenes on Mexican corn landraces and their wild relative teosinte.

Clearly, these issues can be extended to all crops in their respective centers of domestication (for a list of crops and their centers of domestication, see Gepts n.d.). With regard to genetic diversity, the wild progenitors of crops are potentially of more concern because it is now well established that they contain more diversity than their respective crops. Domestication has induced marked bottlenecks in genetic diversity in most, if not all, crops analyzed (Doebley, 1992; Gepts, 1993). Therefore, there is an untapped reservoir of genetic diversity among the wild progenitors of crop plants. It is this reservoir that may potentially be more threatened by gene flow with domesticated types, whether transgenic or not. Figure 2 illustrates the complexity of experimentation that needs to be conducted to determine whether gene flow from a transgenic crop to its wild relative leads to long-term transgene escape (i.e., whether the transgene will effectively introgress into the wild population). Gene flow can be conceived of as a series of successive steps, each of which is necessary for the next step to occur, until transgenes become established (lower box in Fig. 2). For a more detailed analysis of some of the steps in this process, see the review by Jenczewski et al. (2003). Each of these steps can be investigated with a series of experiments. The flow of experiments illustrated here is an oversimplification for several reasons. Each step actually consists of several experiments that may take several years. In addition, the outcome is most likely not a yes or a no as pictured here, but rather a quantitative response, such as a frequency reflecting fine-scale genetic and environmental circumstances.

The different steps to consider are the following:

(1) Wild relatives: To have transgene escape to wild relatives, these have to grow within pollen/seed dispersal range of the transgenic crops. Many crops in most regions 


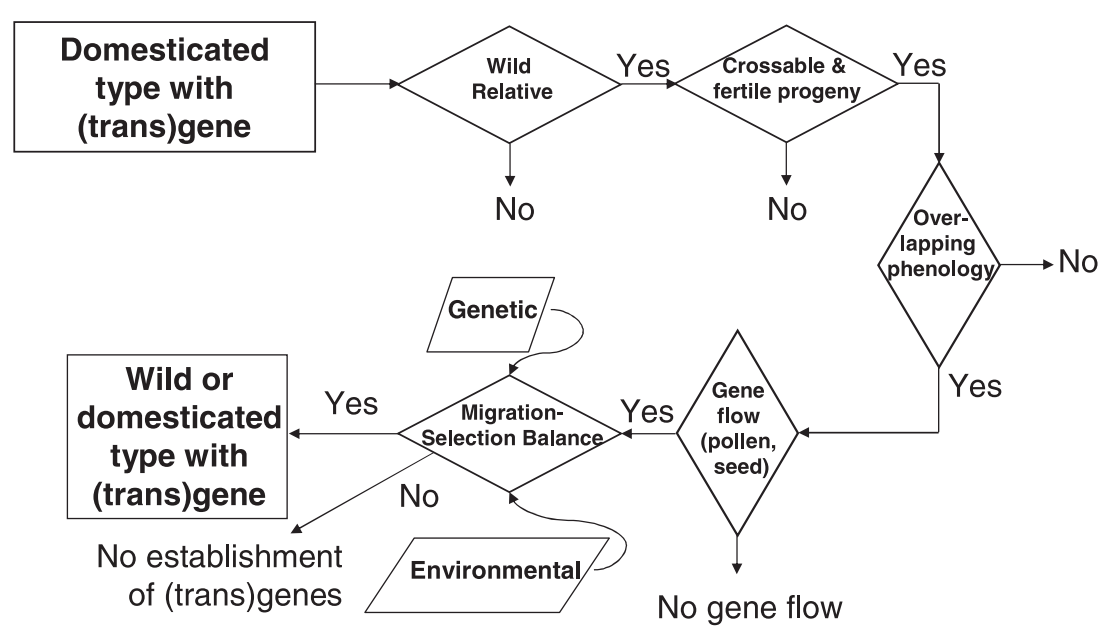

Figure 2. Pathway of escape of (trans)genes from domesticated to other domesticated or wild populations. For further explanations, see text. of the world have been exported from their respective centers of origin (for examples, see http://agronomy.ucdavis.edu/gepts/pb143/lec10/pb143110.htm). Hence, they will not generally have close wild relatives in most of their areas of cultivation. For example, maize, cotton (Gossypium hirsutum L.), and soybean (Glycine max L.) have no close wild relatives in the USA because the former two were domesticated in Mexico or South America, and the latter one in China. In addition, they have no related weeds in the USA. On the other hand, sunflower (Helianthus annuus L.) and strawberries (Fragaria ananassa Douch.) have wild relatives in the USA, which is their center of origin. In other cases, wild related species different from the wild progenitors are present in areas of crop introduction (e.g., Gossypium spp. related to cotton in Australia and johnsongrass, Sorghum halepense (L.) Persoon in North America and Europe). The rice and sorghum cases also illustrate that crops can have weedy, invasive relatives with a cosmopolitan distribution (e.g., red rice, Oryza sativa; johnsongrass). For these crops, potential escape of transgenes may become an issue, assuming that viable and fertile hybrids can appear (see next step). Likewise, the government of Mexico has instituted a moratorium on the deployment of transgenic maize cultivars because of uncertainties associated with the ecological effects of transgenes as these make their way not only into local maize cultivars but also into native wild maize (teosinte, especially Zea mays L. ssp. parviglumis Iltis and Doebley and mexicana Iltis and Doebley) populations. In addition, such factors as the mating system (e.g., autogamy) and the frequency of pollinators will also affect the possibility of transgene escape. Empirical data show, however, that these are not significant barriers especially when considered over large areas and multiple years as shown by results in squash, Cucurbita L. spp. (Montes-Hernández and Eguiarte, 2002).

(2) Crosses yield viable and fertile progeny: For transgenes to escape, transgenic crops have to be able to mate with their wild relatives and these matings have to yield viable and fertile progeny. This may sound selfevident, but needs to be verified. There has to be a minimum of fertility so that the progeny can backcross to the wild progenitor to maintain the transgenes in the gene pool of the wild relative. Crops and their immediate progenitors (from which they were domesticated) both belong to Gene Pool I (Fig. 1), and will therefore normally yield viable and fertile hybrids. In numerous crop species, exceptions have been identified. In maize, for example, the teosinte crossing barrier 1 gene (tcbl) prevents gene flow among some, but not all, populations of maize and its progenitor teosinte (Evans and Kermicle, 2001). Thus, the geographic distribution of these specific genes should be determined to assess the risk of gene flow.

(3) In field or natural environments, a necessary, but not sufficient, condition for gene flow is synchrony, or at least a partial overlap, between crops and their wild relatives for their flowering times. It is only when these flowering times coincide that pollen from one can make its way to the pistil of the other and potentially effect fertilization.

(4) Assuming that pollen is in a position to effect fertilization, the progeny will have to have a certain degree of viability and fertility. Even a partial viability and fertility will allow transgenes to be transmitted as long as full viability and fertility is restored in subsequent generations. This could be achieved, for example, by 


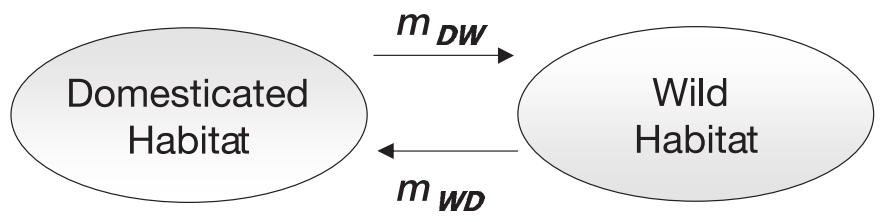

$\begin{array}{lll}\begin{array}{l}\text { Relative } \\ \text { fitness } \\ \text { of allele }\end{array} & A 1 & 1 \\ & & \\ & s \text { selective advantage of } A 1 \text { over } A 2 \\ & e \text { environmental effect } \\ & m \text { migration }\end{array}$

spontaneous backcrossing of the hybrid progeny to the wild relative populations. Research into these four steps have shown that whenever these conditions are satisfied, there will almost certainly be gene flow (Ellstrand et al., 1999).

(5) The last and most critical, and certainly most difficult, step to ascertain is the long-term survival of transgenes from domesticated populations in wild populations. This survival is dependent on a migrationselection balance (Fig. 3). This figure posits a twoenvironment system with a single locus and two alleles. Let us assume an initial $A l$ allele at the $A$ locus, which confers the same fitness in both environments, in this case a natural environment and a cultivated field. A mutation in the $A 1$ allele generates the $A 2$ allele, which confers a fitness advantage, $s$, in the cultivated environment. As an example, locus $A$ could be a gene controlling a domestication trait, such as seed dispersal or compact growth habit. Thus, the transition from $A 1$ to $A 2$ could represent a change from seeds being dispersed to seeds remaining on the plant at maturity. Depending on the specific harvest system, seeds from plants without seed shattering $(A 2)$ will be harvested more readily than plants that disperse their seeds (Al). Therefore, selection favoring the lack of seed shattering and replanting of the seeds over consecutive generations will lead to an increase of the frequency of $A 2 A 2$ plants and the $A 2$ allele will come to dominate in the cultivated environment.

Let us further assume that the cultivated and wild environments are linked by gene flow, $m_{D W}$ from the domesticated to the wild population and $m_{W D}$ in the opposite direction. Wild plants carrying the $A 2$ allele will be at a disadvantage because they will fail to disperse their seeds, hence the positive selection factor will be decreased by a factor $e$ (Fig. 3). Whether this negative selection will cause the $A 2$ allele to disappear from wild populations depends on the net migration into wild populations from domesticated populations. If this migration is sufficiently high, it may replenish the wild population with $A 2$ alleles. One can calculate a threshold value for $m$ given $s$ and $e$, above which $A 2$ will increase in frequency to fixation (i.e., a frequency of $100 \%$ ) in spite of the fact that $A 2$ does not confer optimum adaptation. This replacement of alleles of one population by alleles of another through gene flow has been called genetic assimilation or genetic extinction (see also below). Although the $A 2$ allele would confer less than optimal adaptation in the wild population, it would necessarily predominate by the sole virtue of the sheer magnitude of gene flow from domesticated to wild populations. This phenomenon would be further worsened when wild populations are small, a frequent occurrence for the relatives of crop plants, which suffer from habitat destruction (e.g., common bean, Phaseolus vulgaris; Debouck et al., 1993; Freyre et al., 1996). Under these circumstances, wild populations would also be distinctly changed and could not be considered wild anymore. Below the threshold value for $m$ mentioned earlier, the polymorphism is maintained and both $A l$ and $A 2$ alleles co-exist. The preceding example considered negative selection against a domestication allele in the wild gene pool. One can also consider the effect of positive selection, which may facilitate the establishment of genes from the domesticated gene pool in the wild gene pool. An example of genes under positive selection could be genes conferring disease or pest resistance (whether they are transgenes or originate in the crop gene pool). Whether these genes are actually under positive selection in wild environments needs to be determined empirically because wild environments are inherently 
Review: Effects of crop gene flow on genetic diversity

Table 1. Summary of experiments comparing introgression of genes from crops to sympatric and allopatric wild populations.

\begin{tabular}{|c|c|c|c|c|c|}
\hline Source & Crop & $\begin{array}{c}\text { Sympatric/allopatric } \\
\text { populations? }\end{array}$ & Markers & Method & Results \\
\hline $\begin{array}{l}\text { Bartsch et al. } \\
1999\end{array}$ & Beet & $26 \mathrm{D} ; 65 \mathrm{~W}^{\mathrm{a}}$ & $\begin{array}{l}\text { Allozymes: } \\
12 \text { loci }\end{array}$ & Unique alleles & $\begin{array}{l}\text { (a) Gene flow from D to W. } \\
\text { (b) Slight increase in diversity. } \\
\text { (c) Maintained morphological dif- } \\
\text { ferences between W and D. }\end{array}$ \\
\hline $\begin{array}{l}\text { Linder et al. } \\
1998\end{array}$ & Sunflower & $\begin{array}{l}3 \mathrm{~W} \text {, sympatric; } 4 \mathrm{~W} \text {, } \\
\text { allopatric }\end{array}$ & $\begin{array}{l}\text { RAPD: } 18 \\
\text { (absent in } \\
\text { allopatric) }\end{array}$ & Unique alleles & $\begin{array}{l}\text { High level of crop-specific } \\
\text { markers in sympatric W: } \\
0.32-0.38\end{array}$ \\
\hline
\end{tabular}

${ }^{\mathrm{a}} \mathrm{D}$ : domesticated; W: wild.

quite different from cultivated environments (see next section).

A recent mathematical modeling study (Haygood et al., 2003), expanding on previous simulation studies of Huxel (1999) and Wolf et al. (1991), provides additional insights on the conditions in which gene flow will lead to genetic assimilation. A negatively selected domesticated allele will nevertheless become fixed when the migration rate exceeds the selection coefficient. Furthermore, when a disfavored domesticated allele has been maintained at a moderate frequency, a small, even temporary, increase in immigration can lead to fixation. Genetic assimilation is aggravated by demographic swamping, a situation arising when the hybrids are less fertile than their wild parents. As the wild populations is reduced in size, its share of the total pollen mass decreases also. Alternatively, when the hybrids are more fertile than their wild parents, hybrids may become invasive. An example are aggressive weedy relatives resulting from domesticated $\times$ wild crosses in seven of the world's most important crops (Ellstrand et al., 1999).

Finally, it should be mentioned that there is an additional form of gene flow, namely the dispersal of seeds. This dispersal can take place in a variety of ways, including mechanical (transportation, farm equipment), wind, and animals. Farmers in developing countries regularly exchange seed stocks or obtain new seed stocks from family or members of the same village (Louette et al., 1997). In summary, gene flow can lead to the escape of transgenes to wild populations of relatives. Whether or not this actually happens and if it actually has an ecologically significant effect needs to be determined carefully, and not just assumed or dismissed with a sleight of hand.

There are remarkably few quantitative data on gene flow and its ecological impact, especially in crop species with regard to gene flow between domesticated and wild progenitor types. Crops and their wild progenitors exchange genes (Ellstrand et al., 1999), consistent with the fact that they generally belong to the same biological species (Harlan and de Wet, 1971). However, there are few studies that compare introgression of genes from domesticated types between sympatric and allopatric populations. The few crops with information published in refereed journals include beets (Beta vulgaris L.) (Bartsch and Ellstrand, 1999; Bartsch et al., 1999) and sunflower (Helianthus annuus L.) (Linder et al., 1998). A review of the methodology of these experiments and the conclusion that can be inferred from them are presented in Table 1.

Examples of genetic assimilation or extinction by displacement of native allelic diversity are provided primarily by non-crop plants, including wild walnut (Juglans californica Wats. var. californica) in California (http://sandiego.sierraclub.org/rareplants/130.html; http://www.savemountwashington.org/welcome/FFWALNUT.HTM) and Catalina mountain mahogany (Cercocarpus traskiae Eastw.; Rieseberg and Gerber, 1995) on Catalina Island off the coast of California. Among crop plants, some Mediterranean and tropical trees, including date palm (Phoenix dactylifera L.), olive (Olea europea L.), and coconut (Cocos nucifera L.), have few remaining truly wild populations (e.g., olive: Bronzini de Caraffa et al., 2002). Many supposedly wild populations are either escapes from cultivation, remnants of ancient groves, or hybrids between wild and domesticated types.

\section{THE EFFECT OF GENE FLOW IN THE PRESENCE OF TRANSGENES}

Two aspects particularly deserve discussion. First, will the transgene be subject to selection (positive or negative) or be neutral in wild populations? Second, if it is subject to selection, what is the effect on the rest of the 
genome of the wild populations? The addition of transgenes could lead to a change in allele frequencies through a selective advantage conferred by transgenes in wild populations. However, the advantage conferred by, for example, virus or pest resistance in domesticated populations may not necessarily exist to the same degree in wild populations. Other mechanisms exist to maintain disease or pest pressure at a lower level in wild populations compared to those found in the standard monocultures. For example, resistance to seed weevils [Acanthoscelides obtectus (Say.)] in common bean is conditioned by a small multigene family located in a single, complex locus (Osborn et al., 1986; 1988). This resistance was found initially only in wild populations of common bean, presumably because they had not been included in the domesticated gene pool as a consequence of the domestication genetic bottleneck in common bean (Sonnante et al., 1994). Nevertheless, in those populations in which weevil resistance genes have been found, they do not occur at high frequencies, suggesting that there is not a high selection pressure to maintain these genes at a high frequency (although alternative explanations can be proposed as well). In contrast to domesticated beans, where large amounts of stored bean seeds facilitate the fast development of weevil populations, seeds of wild beans occur mainly individually in soil seed banks. Wild bean seed populations are therefore unable to sustain large weevil populations. In addition, weevils are host to a suite of hyperparasites and predators (Delgado Salinas et al., 1988), which also keep weevil populations at a low density in wild populations. This example shows that genes that confer a positive selection advantage in domesticated populations (whether obtained by transgenesis or by classical plant breeding) may not necessarily do so in wild populations.

Effects of crop genes on the fitness in wild populations need to be measured directly in these populations. Bartsch et al. (1996) showed that hybrid sugarbeet with transgenic virus resistance had higher productivity (fresh weight of root and leaves) than the non-transgenic hybrid in the presence of beet necrotic yellow vein virus. In the absence, there were no differences. Stewart et al. (1997) showed that defoliation of rapeseed (Brassica napus L.) caused by artificially introduced insect insectivory led to increased reproduction in favor of $B t$ plants. Recently, a study by Snow et al. (2003) showed that the introduction of $B t$ genes into wild sunflower populations resulted in increased seed production. Escape of herbicide resistance genes to populations of wild relatives, some of which are among the most noxious weeds of our major crops, such as red rice for rice and shattercane for sorghum, may mean the loss of effective herbicides, an important tool in the control of these weeds.

Whether or not a transgene will spread into wild populations depends on a number of factors, including the level of gene flow in any given growing season and in successive seasons, and the selective effect of the transgene. As pointed out in the previous section, information on the year-to-year and location-to-location variation of gene flow is rare. In addition, the selective value of a transgene in wild populations may or may not be similar to that in domesticated populations. Further considerations include the degree of dominance, the presence of epistatic interactions, and the existence of genotype $\times$ environment interactions. Depending on the magnitude of these different evolutionary factors, the situation faced by transgenes may amount to a migrationdrift or migration-selection balance.

If the transgene is subject to selection, then it may affect the rest of the genome as well. If the selection is positive (i.e., individuals containing the transgene will be favored), the genome will be subject to a selective sweep or hitchhiking at the locus and surrounding regions. If the selection is negative, the genome will be subject to background selection (Charlesworth et al., 1993). In both cases, selection will lead to reduced diversity at the locus and adjacent regions. Both phenomena can, however, be distinguished based on the frequency spectrum of DNA sequence variants around the gene under selection, especially the presence (hitchhiking) or absence (background selection) of high-frequency variants (Charlesworth et al., 1995; Cummings and Clegg, 1998; Fay and Wu, 2000; Yi and Charlesworth, 2000).

The size of the affected region subject to reduction in genetic diversity ("genomic window") is proportionate to $s / r$, where $s$ is the selective advantage of the gene under selection and $r$ is the level or recombination. For outcrossing individuals, characterized by high levels of heterozygosity and therefore effective recombination, the region of the genome that remains linked around the transgene can be very small (of the order of 500$10000 \mathrm{bp}$ out of a total genome size of $2.5 \times 10^{9} \mathrm{bp}$ in maize: Bennett and Leitch, 1995; Remington et al., 2001; Wang et al., 1999). In predominantly selfing organisms, the linked region (said to be in "linkage disequilibrium" with the transgene) will be much larger, although data are definitely lacking for plants with this type of mating system. For vegetatively propagated and apomictic plants, the entire genome is in linkage disequilibrium.

Studies of other organisms can provide insights into the effects of selective sweeps or background selection 
on genetic diversity. Insecticide resistance in insects is analogous to the situation of a transgene introduced in a wild population, in that a resistance gene can have a strong, positive selective value in the presence of the insecticide. The prediction that genetic diversity would be reduced around insecticide resistance genes was verified in Aedes aegypti (L.). Populations of this insect had been subjected to DDT and, subsequent to the interdiction of DDT, to organophosphate (OP) insecticides. Reduced genetic diversity and increased population differentiation was found around an OP resistance locus, but not a DDT resistance locus. The latter was presumably due to re-equilibration of the population following the discontinuation of the application of DDT (Yan et al., 1998). Integration of the genetic and physical maps of $A$. aegypti (Brown et al., 2001) suggests that a marker subject to hitchhiking near the OP resistance locus (Yan et al., 1998) is at least $17 \times 10^{6}$ bp from the resistance locus. For comparison purposes, the size of the $A$. aegypti genome is around $780 \times 10^{6} \mathrm{bp}$ (Brown et al., 2001).

In the fruit fly Drosophila melanogaster (L.), the pattern of genetic variation across the genome reflects the occurrence of multiple selective sweeps. An example is provided by the locus coding for a sperm-specific axonemal dynein protein (Nurminsky et al., 1998) around which diversity is markedly reduced. In the Norway rat [Rattus norvegicus (Berkkenhaut)], extensive linkage disequilibrium over a region of about $11 \mathrm{cM}$ (or $5 \%$ of the rat genome) in highly resistant populations has been demonstrated around a gene for resistance to the anticoagulant warfarin (Kohn et al., 2000). Finally, it may be appropriate to consider a limited number of crop plantwild progenitor pairs that could constitute model systems for the types of experiments considered here. Such studies are under way in maize (Flint-García et al., 2003); however, self-pollinated crops, such as common bean and rice, also deserve attention. Recent studies in common bean have shown a highly asymmetrical gene flow between domesticated and wild types, with a predominance of gene flow from the former to the latter (Papa and Gepts, 2003). This asymmetry may be attributed to a larger domesticated pollen mass in comparison to that of wild types, to the recessiveness of domesticated traits, and/or to stronger selection by farmers against hybrids compared with natural selection against domesticated traits in wild environments. This gene flow is accompanied by background selection as suggested by the maintenance of the domesticated and wild phenotypes in sympatric populations. Hence, wild and domesticated populations of common bean may be a useful experimental model to study the magnitude of linkage disequilibrium in a predominantly selfing species, in contrast with an outcrossing species, such as maize.

In summary, whether or not a transgene from a transgenic source population will become established in sink populations depends on many parameters, including the magnitude of the selective advantage and the migration rate, genetic drift, epistatic effects, and genotype $\times$ environment interactions. These parameters are not inherently different from those governing the fate of non-transgenes subject to gene flow, with the exception of the novelty of transgenes, which makes any prediction more difficult, given the absence of biological and ecological information on the effect of transgenes in their new genetic and environmental backgrounds. Many domestication traits are recessive and represent a loss of function. In addition, they represent adaptations to cultivated environments (Gepts, 2002), such that fully domesticated plants cannot survive without human intervention in the wild (Darwin, 1859). Introduction of domestication genes from non-transgenic crops is, therefore, unlikely to cause severe ecological problems unless recombination of domesticated and wild traits takes place leading to weedy hybrids. Addition of transgenic traits, such as insect resistance, may actually cause in increase in ecological amplitude by releasing wild relatives from certain constraints such as insect pests.

\section{EFFECTS OF TRANSGENIC CULTIVARS ON GENETIC DIVERSITY IN A SOCIO-ECONOMIC CONTEXT}

Transgenic technology did not appear in a vacuum, as it has been part of significant changes in the seed industry over the last twenty years. There has been a shift away from public institutions, mainly land-grant universities, in the area of plant breeding, as documented by Frey (1996). This shift largely correlates with the advent of biotechnology, i.e., the ability to isolate, modify, and transfer genes by recombinant DNA and plant transformation technologies. Concurrently, the intellectual property regime has changed because of the Diamond vs. Chakrabarty (1980) decision of the USA Supreme Court, affirming the validity of a patent for a genetically modified Pseudomonas aeruginosa (Schroeter) bacterium. This was an important decision because it created a precedent by allowing the patenting of life forms.

The combination of the molecular technology and the capability of protecting molecular inventions has led to significant activities in the private sector in the area of 


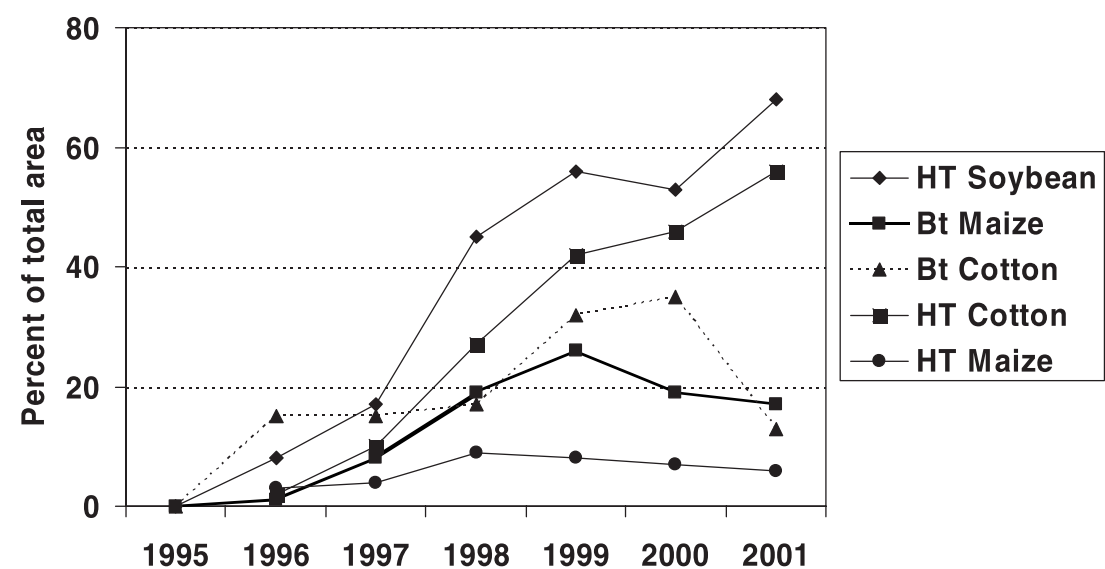

Figure 4. Adoption of herbicide-tolerant (HT) and insect-resistant $(B t)$ crops in the USA Source: FernandezCornejo J, McBride WD. 2002. Adoption of Bioengineered Crops. USDA-ERS: http://www.ers.usda.gov/ publications/aer810/ (consulted May 3, 2003). genetic engineering of crop plants. To make the products available to farmers, however, private companies involved in genetic engineering have had to acquire capabilities in classical plant breeding in order to develop cultivars as vehicles to deliver the results of their genetic engineering technology, such as herbicide or insect resistance. This has been achieved by buying smaller seed companies, which had neither the financial or technological wherewithal to survive in this new environment. This has led to a situation where only five major firms now sell genetically improved seeds: Monsanto, DuPont/Pioneer, Aventis, Syngenta and Dow. These same companies account for about a quarter of total seed sales (Fulton and Giannakas, 2001). For example, in 1998, Monsanto and Pioneer-HiBred controled $15 \%$ and $39 \%$ of the USA maize seed market, respectively. For soybean seed, these companies controlled around $24 \%$ and $17 \%$, respectively, of the market. For USA cotton, Delta \& Pine Land and Stoneville, had $71 \%$ and $16 \%$, respectively, of the seed market (Kalaitzandonakes and Hayenga, 2000). In 1999, $61 \%$ of the cotton area in the USA was planted to a small number of closely related cultivars in which transgenes had been introduced, such as Deltapine 90 and DES56 (USDA Agricultural Marketing Service 1999).

The effect of this increased economic concentration on the genetic diversity of the domesticated gene pool of crops such as soybean, maize, and cotton remains to be determined, especially with regard to the diversity of the cultivars currently grown by farmers. It would come on top of previous episodes of reduction in genetic diversity, such as domestication, dissemination from centers of domestication, and classical plant breeding (Gepts, 1993; 1995). Transgenic cultivars of some field crops now occupy a significant proportion of the acreage (Fig. 4), raising questions about the overall level of genetic diversity in these crops. Because the domesticated gene pool represents only a fraction of the genetic diversity contained in the wild relatives (Gepts, 1993; 1995), it remains to be determined how much genetic diversity is left in the current USA domesticated gene pool prior to the introduction of transgenic varieties, and also whether this introduction would further decrease genetic diversity. The USA soybean germplasm can be traced back to a few ancestral lines imported within the last two centuries (Kisha et al., 1998; Li et al., 2001). The hybrid maize germplasm of the USA is based on a single heterotic combination - involving the Lancaster Sure Crop (flint) and Reid's Yellow Dent complexes (Doebley et al., 1988; Smith, 1995).

If and when these maize hybrids are imported into Mexico, gene flow between these hybrids and native materials such as open-pollinated varieties and wild teosinte populations could presumably introduce some genetic diversity, depending on the gene flow levels and selection regime. At this stage, no comprehensive data are available in the refereed literature on the effect of gene flow between introduced and local maize germplasm in the center of origin of the crop. It is clear, however, that USA maize has been imported into Mexico in recent years (Fig. 5). This maize is destined for food, feed, and industrial purposes but it is not clear to what extent it is transgenic. It is also not known how much of this maize is being planted in spite of the moratorium imposed by the Mexican government.

USA maize is produced at roughly $40 \%$ of the cost of production in Mexico, and average yields vary from 1.8 tons per hectare in Mexico to 8 tons per hectare in the USA (Nadal, 2000). The reduction in price fetched by maize in Mexico (50\% between January 1994 and August 


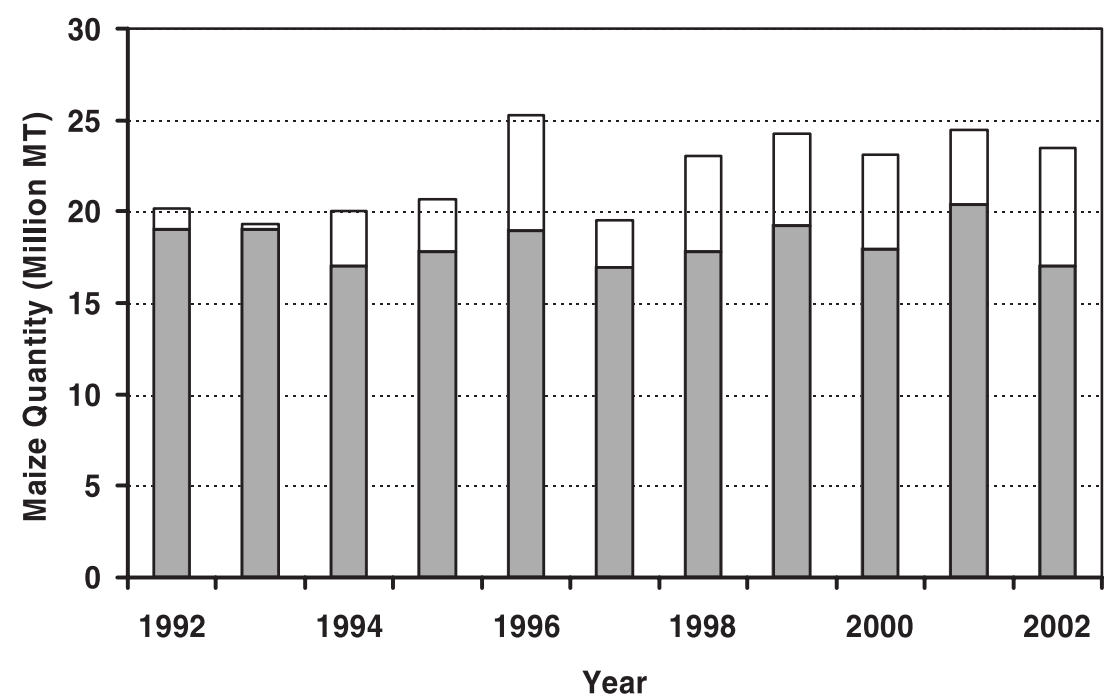

$\square$ Mexican Production $\square$ Import from USA
Figure 5. Relative proportion of Mexican national maize production (hatched) and maize imports from the USA (open). Units: $10^{6}$ MT. Source: USDA-ERS: Foreign Agricultural Trade: http://www.ers.usda.gov/db/fatus/index.asp?Type $=\mathrm{XC}$ and http:// www.fas.usda.gov/psd/complete_files/ GF-0440000.csv (consulted May 3, 2003).
1996) because of cheap imports has led to disruptions in the farming sector in that country, including migration to urban areas and the USA The abandonment of farm employment may have deleterious effects on the genetic diversity of maize in Mexico. Sixty per cent of Mexican producers (1.8 million) use locally adapted corn varieties, covering 80 per cent of the total area under corn cultivation (Nadal, 2000). This discussion shows that although transgenes cannot generally be directly implicated in potential losses of genetic diversity, they are part of a new socio-economic system that may have such an effect. This concern is not unique to transgenic varieties. Classically bred varieties also present this risk. Nor is this concern unique to private breeding programs; it is also present for public breeding programs. Surveys of genetic diversity present in breeding programs such as the maize program at CIMMYT are especially welcome in order to shed light on this issue (Warburton et al., 2002).

\section{CONCLUSIONS}

This discussion provides a framework towards the determination of the potential for gene flow to affect genetic diversity in populations of crop landraces and progenitors, whether transgenes are present or not. A clear outcome of this discussion is that each case needs to be examined on its own merit. Not only the organism, but also the trait, the environment, and even the location of the transgene on the genome can affect the ultimate outcome of gene flow in each case. With regard to the environment, such a discussion on gene flow is particularly timely. Most of the transgenic crop cultivation has taken place in countries where the crops do not have sexually compatible relatives, including landraces. These countries include the USA, Canada, and Argentina. However, the introduction of transgenic maize in Mexico (Quist and Chapela, 2001; 2002) and the potential for China to authorize the commercial planting of transgenic rice and soybean (Huang et al., 2003) are of particular concern.

Several areas remain to be investigated more thoroughly in order to fully understand the impact of gene flow on the genetic diversity of crop landraces and progenitors. What are the long-term effects of gene flow on the genetic diversity of relatives, both landraces and wild populations? This will require both empirical data and modeling studies. Are there regions of the genome that are less "susceptible to invasion" by transgenes, especially with regard to genes for adaptation? What may be the unexpected effects of transgenes introduced into new genetic backgrounds, such as the increased lignification observed in Bt corn (Saxena and Stotzky, 2001), the increased level of outcrossing in transgenic Arabidopsis thaliana (Bergelson et al., 1998), and a decrease in bolting in transgenic beet (Bartsch et al., 2001)? These effects could be attributed to pleiotropic effects of the transgene or position effects resulting from the specific insertion location of the transgene in the genome. Furthermore, what is the effect on stability of insertion in the genome of transgenes when these are moved into different genetic backgrounds? How have the changed socio-economic conditions (consolidation of seed companies involved in 
cultivar development, international trade, patenting of life forms) affected genetic diversity of crops and their landraces and wild relatives? Finally, what is the value of genetic diversity, not only from a biological, but also from a social, cultural, and esthetic standpoint (Pagiola et al., 1998)? Although these topics have received piecemeal attention, more comprehensive studies are needed to fully understand the consequences of gene flow both with or without transgenes unless one is to live with the consequences of a "fait accompli."

\section{ACKNOWLEDGEMENTS}

Our research on gene flow was funded by the McKnight Foundation's program on Collaborative Crop Research. This manuscript originated from a workshop discussion on gene flow organized by A.A. Snow at Ohio State University, Columbus, in April 2002. We thank two anonymous reviewers for comments, which improved the manuscript.

Received January 13, 2003; accepted May 16, 2003.

\section{REFERENCES}

Albagli S (2002) Implementation of the Convention on Biological Diversity in Brazil. In Encyclopedia of Life Supporting Systems (EOLSS), developed under the Auspices of the UNESCO. EOLSS Publishers, Oxford, UK

Bartsch D, Ellstrand NC (1999) Genetic evidence for the origin of Californian wild beets (genus Beta). Theor. Appl. Genet. 99: 1120-1130

Bartsch D, Schmidt M, Pohl-Orf M, Haag C, Schuphan I (1996) Competitiveness of transgenic sugar beet resistant to beet necrotic yellow vein virus and potential impact on wild beet populations. Mol. Ecol. 5: 199-205

Bartsch D, Lehnen M, Clegg J, Pohl-Orf M, Schuphan I, Ellstrand NC (1999) Impact of gene flow from cultivated beet on genetic diversity of wild sea beet populations. Mol. Ecol. 8: 1733-1741

Bartsch D, Brand U, Morak C, Pohl-Orf M, Schuphan I, Ellstrand NC (2001) Biosafety of hybrids between transgenic virus-resistant sugar beet and Swiss chard. Ecol. Appl. 11: 142-147

Beets WC (1982) Multiple cropping and tropical farming systems. Westview Press, Aldershot, Hants, UK.

Bennett MD, Leitch IJ (1995) Nuclear DNA amounts in angiosperms. Ann. Bot. 76: 113-176

Bergelson J, Purrington CB, Wichmann G (1998) Promiscuity in transgenic plants. Nature 395: 25-25

Bronzini de Caraffa V, Maury J, Gambotti C, Breton C,
Bervillé A, Giannettini J (2002) Mitochondrial DNA variation and RAPD mark oleasters, olive and feral olive from Western and Eastern Mediterranean. Theor. Appl. Genet. 104: 1209-1216

Brown SE, Severson DW, Smith LA, Knudson DL (2001) Integration of the Aedes aegypti mosquito genetic linkage and physical maps. Genetics 157: 1299-1305

Brush SB (1995) In situ conservation of landraces in centers of crop diversity. Crop Sci. 35: 346-354

Bulmer MG (1972) Multiple niche polymorphism. Am. Nat. 106: $254-257$

Charlesworth B, Morgan MT, Charlesworth D (1993) The effects of deleterious mutations on neutral molecular variation. Genetics 134: 1289-1303

Charlesworth D, Charlesworth B, Morgan MT (1995) The pattern of neutral molecular variation under the background selection model. Genetics 141: 1619-1632

Convention on Biological Diversity (1992) Convention text. http://www.biodiv.org/convention/articles.asp. (Accessed: May 4, 2003)

Cummings MP, Clegg MT (1998) Nucleotide sequence diversity at the alcohol dehydrogenase 1 locus in wild barley (Hordeum vulgare ssp. spontaneum) - an evaluation of the background selection hypothesis. Proc. Nat. Acad. Sci. USA 95: 5637-5642

Darwin C (1859) On the origin of species by means of natural selection. J. Murray, London

Debouck DG, Toro O, Paredes OM, Johnson WC, Gepts P (1993) Genetic diversity and ecological distribution of Phaseolus vulgaris in northwestern South America. Econ. Bot. 47: 408-423

Delaney DE, Bliss FA (1991a) Selection for increased percentage phaseolin in common bean. 1. Comparison of selection for seed protein alleles and $\mathrm{S}_{1}$ family recurrent selection. Theor. Appl. Genet. 81: 301-305

Delaney DE, Bliss FA (1991b) Selection for increased percentage phaseolin in common bean. 2. Changes in frequency of seed protein alleles with $S_{1}$ family recurrent selection. Theor. Appl. Genet. 81: 306-311

Delgado Salinas A, Bonet A, Gepts P (1988) The wild relative of Phaseolus vulgaris in Middle America. In Gepts P, ed, Genetic resources of Phaseolus beans. Kluwer, Dordrecht, the Netherlands, pp 163-184

Diamond vs. Chakrabarty (1980) 447 USA 303. United States Supreme Court. http://supct.law.cornell.edu/supct/cases/447 us303.htm. (Accessed: May 4, 2003)

Doebley J (1992) Molecular systematics and crop evolution. In Soltis PS, Soltis DE, Doyle JJ, eds, Molecular systematics of plants. Chapman Hall, New York, pp 202-222

Doebley JF, Wendel JD, Smith JSC, Stuber CW, Goodman MM (1988) The origin of cornbelt maize: the isozyme evidence. Econ. Bot. 42: 120-131

Ellstrand NC, Prentice HC, Hancock JF (1999) Gene flow and introgression from domesticated plants into their wild relatives. Annu. Rev. Ecol. Syst. 30: 539-563 
Evans MMS, Kermicle JL (2001) Teosinte crossing barrier1, a locus governing hybridization of teosinte with maize. Theor. Appl. Genet. 103: 259-265

Fay JC, Wu CI (2000) Hitchhiking under positive Darwinian selection. Genetics 155: 1405-1413

Flint-Garcia SA, Thornsberry JM, Buckler SE (2003) Structure of linkage disequilibrium in plants. Annu. Rev. Plant Biol. 54: 357-374

Francis CA (1985) Variety development for multiple cropping systems. Crit. Rev. Plant Sci. 3: 133-168

Francis CA (1986) Multiple cropping systems. Macmillan, New York

Frey KJ (1975) Plant breeding in the seventies: useful genes from wild plant species. Egypt. J. Genet. Cytol. 5: 460-482

Frey KJ (1996) National Plant Breeding Study. I. Human and financial resources devoted to plant breeding research and development in the United States in 1994. Ames, IA: Iowa State University

Freyre R, Ríos R, Guzmán L, Debouck DG, Gepts P (1996) Ecogeographic distribution of Phaseolus spp. (Fabaceae) in Bolivia. Econ. Bot. 50: 195-215

Fulton M, Giannakas K (2001) Agricultural biotechnology and industry structure. AgBioForum 4: http://www.agbioforum.org/Default/vol4no2ar8fulton.htm. (Accessed: May 4, 2003)

Geffroy V, Sicard D, de Oliveira JCF, Sévignac M, Cohen S, Gepts P, Neema C, Dron M (1999) Identification of an ancestral resistance gene cluster involved in the coevolution process between Phaseolus vulgaris and its fungal pathogen Colletotrichum lindemuthianum. Mol. Plant Microbe In. 12: 774-784

Geffroy V, Sévignac M, De Oliveira JCF, Fouilloux G, Skroch P, Thoquet P, Gepts P, Langin T, Dron M (2000) Inheritance of partial resistance against Colletotrichum lindemuthianum in Phaseolus vulgaris and co-localization of QTL with genes involved in specific resistance. Mol. Plant Microbe In. 13: 287-296

Gepts P (1993) The use of molecular and biochemical markers in crop evolution studies. Evol. Biol. 27: 51-94

Gepts P (1995) Genetic markers and core collections. In Hodgkin T, Brown A, van Hintum TJL, Morales E, eds, Core collections of plant genetic resources. Wiley, New York, pp 127-146

Gepts P (2000) A phylogenetic and genomic analysis of crop germplasm: a necessary condition for its rational conservation and utilization. In Gustafson J, ed, Proc. Stadler Symposium, Plenum. New York, pp 163-181

Gepts P (2001) Origins of plant agriculture and major crop plants. In Tolba $\mathrm{M}$, ed, Our fragile world: Challenges and opportunities for sustainable development. EOLSS Publishers, Oxford, pp 629-637

Gepts P (2002) A comparison between crop domestication, classical plant breeding, and genetic engineering. Crop Sci. 42: $1780-1790$
Gepts P (n.d.) Evolution of crop plants. agronomy.ucdavis.edu/ gepts/pb143/pb143.htm. (Accessed: May 4, 2003)

Goodman RM, Newell N (1985) Genetic engineering of plants for herbicide resistance: status and prospects. In Halvorson $\mathrm{H}$, Pramer D, Rogul M, eds, Engineered organisms in the environment: scientific issues, American Society for Microbiology. Washington, D.C., pp 47-53

Hancock JF, Grumet R, Hokanson SC (1996) The opportunity for escape of engineered genes from transgenic crops. HortScience 31: 1080-1085

Harlan JR, de Wet JMJ (1971) Towards a rational classification of cultivated plants. Taxon 20: 509-517

Hauser TP, Shaw RG, Østergård H (1998a) Fitness of F1 hybrids between weedy Brassica rapa and oilseed rape (B. napus). Heredity 81: 429-435

Hauser TP, Jørgensen RB, Østergård H (1998b) Fitness of backcross and F2 hybrids between weedy Brassica rapa and oilseed rape (B. napus). Heredity 81: 436-443

Haygood R, Ives AR, Andow DA (2003) Consequences of recurrent gene flow from crops to wild relatives. Proc. Royal Soc. London B, Biol Sci.: in press

Heywood VH, Watson RT, United Nations Environment Programme (1995) Global biodiversity assessment. Cambridge University Press, Cambridge

Huang J, Rozelle S, Pray C, Wang Q (2002) Plant biotechnology in China. Science 295: 674-676

Huxel GR (1999) Rapid displacement of native species by invasive species: effects of hybridization. Biol. Conserv. 89: $143-152$

Jenczewski E, Ronfort J, Chèvre A-M (2003) Crop-to-wild gene flow, introgression and possible fitness effects of transgenes. Environ. Biosafety Res. 2: 9-24

Kalaitzandonakes N, Hayenga M (2000) Structural change in the biotechnology and seed industrial complex: Theory and evidence. In Lesser W, ed, Transitions in Agbiotech: Economics of Strategy and Policy, Food Marketing Policy Center. University of Connecticut, Storrs, CT

Kelly JD, Kolkman JM, Schneider K (1998) Breeding for yield in dry bean (Phaseolus vulgaris L.). Euphytica 102: 343-356

Kisha TJ, Diers BW, Hoyt JM, Sneller CH (1998) Genetic diversity among soybean plant introductions and North American germplasm. Crop Sci. 38: 1669-1680

Koenig R, Gepts P (1989) Segregation and linkage of genes or seed proteins, isozymes, and morphological traits in common bean (Phaseolus vulgaris). J. Hered. 80: 455-459

Kohn MH, Pelz H-J, Wayne RK (2000) Natural selection mapping of the warfarin-resistance gene. Proc. Nat. Acad. Sci. USA 97: 7911-7915

Lenormand T (2002) Gene flow and the limits to natural selection. Trends Ecol. Evol. 17: 183-189

Li ZL, Qiu LJ, Thompson JA, Welsh MM, Nelson RL (2001) Molecular genetic analysis of USA and Chinese soybean ancestral lines. Crop Sci. 41: 1330-1336 
Linder CR, Taha I, Seiler GJ, Snow AA, Rieseberg LH (1998) Long-term introgression of crop genes into wild sunflower populations. Theor. Appl. Genet. 96: 339-347

Loreau M, Behera N (1999) Phenotypic diversity and stability of ecosystem processes. Theor. Popul. Biol. 56: 29-47

Louette D, Charrier A, Berthaud J (1997) In situ conservation of maize in mexico - genetic diversity and maize seed management in a traditional community. Econ. Bot. 51: 20-38

Marek LF, Mudge J, Darnielle L, Grant D, Hanson N, Paz M, Yan HH, Denny R, Larson K, Foster-Hartnett D, Cooper A, Danesh D, Larsen D, Schmidt T, Staggs R, Crow JA, Retzel E, Young ND, Shoemaker RC (2001) Soybean genomic survey: BAC-end sequences near RFLP and SSR markers. Genome 44: 572-581

Martin GB, Adams MW (1987a) Landraces of Phaseolus vulgaris (Fabaceae) in northern Malawi. I. Regional variation. Econ. Bot. 41: 190-203

Martin GB, Adams MW (1987b) Landraces of Phaseolus vulgaris (Fabaceae) in northern Malawi. II. Generation and maintenance of variability. Econ. Bot. 41: 204-215

McKay JK, Latta RG (2002) Adaptive population divergence: markers, QTL and traits. Trends Ecol. Evol. 17: 285-291

Montes-Hernández S, Eguiarte LE (2002) Genetic structure and indirect estimates of gene flow in three taxa of Cucurbita (Cucurbitaceae) in western Mexico. Am. J. Bot. 89: 11561163

Nadal A (2000) The environmental and social impacts of economic liberalization on corn production in Mexico. WWF, Geneva and Oxfam, Oxford, UK

Nurminsky DI, Nurminskaya MV, De Aguiar D, Hartl DL (1998) Selective sweep of a newly evolved sperm-specific gene in Drosophila. Nature 396: 572-575

Osborn TC, Blake T, Gepts P, Bliss FA (1986) Bean arcelin. 2. Genetic variation, inheritance and linkage relationships of a novel seed protein of Phaseolus vulgaris. Theor. Appl. Genet. 71: 847-855

Osborn TC, Alexander DC, Sun SSM, Cardona C, Bliss FA (1988) Insecticidal activity and lectin homology of arcelin seed protein. Science 240: 207-210

Pagiola S, Kellenberg J, Vidaeus L, Srivastava J (1998) Mainstreaming biodiversity in agricultural development. Finance Dev. March 1998: 38-41; http://www.worldbank. org/fandd/english/pdfs/0398/060398.pdf

Papa R, Gepts P (2003) Asymmetry of gene flow and differential geographical structure of molecular diversity in wild and domesticated common bean (Phaseolus vulgaris L.) from Mesoamerica. Theor. Appl. Genet. 106: 239-250

Quist D, Chapela IH (2001) Transgenic DNA introgressed into traditional maize landraces in Oaxaca, Mexico. Nature 414: $541-543$

Quist D, Chapela IH (2002) Biodiversity (Communications arising (reply)): Suspect evidence of transgenic contamination/Maize transgene results in Mexico are artefacts. Nature 416: $602-602$
Rafalski JA, Tingey SV (1993) Genetic diagnostics in plant breeding - RAPDs, microsatellites and machines. Trends Genet. 9: 275-280

Reed DH, Frankham R (2001) How closely correlated are molecular and quantitative measures of genetic variation? A meta-analysis. Evolution 55: 1095-1103.

Remington DL, Thornsberry JM, Matsuoka Y, Wilson LM, Whitt SR, Doeblay J, Kresovich S, Goodman MM, Buckler ES (2001) Structure of linkage disequilibrium and phenotypic associations in the maize genome. Proc. Nat. Acad. Sci. USA 98: 11479-11484

Rick C (1982). The potential of exotic germplasm for tomato improvement. In Vasil I, Scowcroft W, Frey K, eds, Plant improvement and somatic cell genetics. Academic Press, New York, pp 1-42

Rieseberg LH, Gerber D (1995) Hybridization in the Catalina Island Mountain Mahogany (Cercocarpus traskiae): RAPD evidence. Conserv. Biol. 9: 199-203

Saxena D, Stotzky G (2001) Bt corn has a higher lignin content than non-Bt corn. Am. J. Bot. 88: 1704-1706

Schultheis JR, Wehner TC, Walters SA (1997) Mixtures of cucumber cultigens affect yield in a multiple-harvest system. Hortscience 32: 1024-1027

Schünmann PHD, Coia G, Waterhouse PM (2002) Biopharming the SimpliRED (TM) HIV diagnostic reagent in barley, potato and tobacco. Mol. Breeding 9: 113-121

Singh SP, Nodari R, Gepts P (1991) Genetic diversity in cultivated common bean. I. Allozymes. Crop Sci. 31: 19-23

Singh SP, Molina A, Gepts P (1995) Potential of wild common bean for seed yield improvement of cultivars in the tropics. Can. J. Plant Sci. 75: 807-813

Smith CW (1995) Crop production: evolution, history, and technology. Wiley, New York

Snow AA (2002) Transgenic crops - why gene flow matters. Nature Biotechnol. 20: 542-542

Snow AA, Moran-Palma P, Rieseberg LH, Wszelaki A, Seiler G (1998) Fecundity, phenology, and see dormancy of F1 wild-crop hybrids in sunflower (Helianthus annuus, Asteraceae). Am. J. Bot. 85: 794-801

Snow A, Pilson D, Rieseberg L, Paulsen M, Pleskac N, Reagon M, Wolf D, Selboa S (2003) A Bt transgene reduces herbivory and enhances fecundity in wild sunflowers. Ecol. App. 13: 279-286

Sonnante G, Stockton T, Nodari RO, Becerra Velásquez VL, Gepts P (1994) Evolution of genetic diversity during the domestication of common-bean (Phaseolus vulgaris L.). Theor. Appl. Genet. 89: 629-635

Stalker HT (1980) Utilization of wild species for crop improvement. Adv. Agron. 33: 111-147

Stewart CN, All JN, Raymer PL, Ramachandran S (1997) Increased fitness of transgenic insecticidal rapeseed under insect selection pressure. Mol. Ecol. 6: 773-779

Stoger E, Vaquero C, Torres E, Sack M, Nicholson L, Drossard J, Williams S, Keen D, Perrin Y, Christou P, Fischer R (2000) Cereal crops as viable production and 
storage systems for pharmaceutical $\mathrm{scFv}$ antibodies. Plant Mol. Biol. 42: 583-590

Tanksley SD, McCouch SR (1997) Seed banks and molecular maps: unlocking genetic potential from the wild. Science 277: 1063-1066

USDA - Agricultural Marketing Service (1999). Cotton varieties planted - 1999 crop, Agricultural Marketing Service, Memphis, TN, USA

van Tienderen PH, de Haan AA, van der Linden CG, Vosman B (2002) Biodiversity assessment using markers for ecologically important traits. Trends Ecol. Evol. 17: 577-582

Wang R-L, Stec A, Hey J, Lukens L, Doebley J (1999) The limits of selection during maize domestication. Nature 398: 236-239

Wang R-L, Stec A, Hey J, Lukens L, Doebley J (2001) correction: The limits of selection during maize domestication. Nature 410: 718

Warburton ML, Xianchun X, Crossa J, Franco J, Melchinger AE, Frisch M, Bohn M, Hoisington D (2002) Genetic characterization of CIMMYT inbred maize lines and open pollinated populations using large scale fingerprinting methods. Crop Sci 42: 1832-1840

Whitt SR, Wilson LM, Tenaillon MI, Gaut BS, Buckler ES, (2002) Genetic diversity and selection in the maize starch pathway. Proc. Nat. Acad. Sci. USA 99: 12959-12962

Wolf DE, Takebayashi N, Rieseberg LH (2001) Predicting the risk of extinction through hybridization. Conserv. Biol. 15: $1039-1053$

Wood D, Lenné JM (1999) Agrobiodiversity: characterization, utilization, and management. New York, Wallingford, Oxon CABI Pub

Yan GY, Chadee DD, Severson DW (1998) Evidence for genetic hitchhiking effect associated with insecticide resistance in Aedes aegypti. Genetics 148: 793-800

Yi S, Charlesworth B (2000) A selective sweep associated with a recent gene transposition in Drosophila miranda. Genetics 156: 1753-1763

Zane L, Bargelloni L, Patarnello T (2002) Strategies for microsatellite isolation: a review. Mol. Ecol. 11: 1-16

Zhu YY, Chen HR, Fan JH, Wang YY, Li Y, Chen JB, Fan JX, Yang SS, Hu LP, Leung H, Mew TW, Teng PS, Wang ZH, Mundt CC (2000) Genetic diversity and disease control in rice. Nature 406: $718-722$
To access this journal online: www.edpsciences.org 